\title{
PENGARUH PADAT PENEBARAN YANG BERBEDA TERHADAP KELANGSUNGAN HIDUP DAN PERTUMBUHAN LARVA IKAN BAUNG (Mystus numerus)
}

\author{
M. Sugihartono ${ }^{1}$, Muarofah Ghofur ${ }^{2}$, Satrio $^{3}$ \\ 1 Dosen Program Studi Budidaya Perairan \\ 2 Dosen Program Studi Budidaya Perairan \\ 3 Mahasiswa Program Studi Budidaya Perairan \\ Program Studi Budidaya Perairan, Fakultas Pertanian, Universitas Batanghari \\ Jalan Slamet Riyadi, Broni, Jambi 36122, Telp. +62074160103 \\ *email korespondensi: $\underline{\text { ___shartono@yahoo.com }}$
}

\begin{abstract}
Baung fish is an endogenous fish of Indonesia. This is a fresh water fish. One of those effort to anticipate the decrease of the aquaculture product itself is to develop the aquaculture sustainability. The problem of hatching baung fish larvae are the low survival rate and the growth of larvae in high density farmed. Therefore, it needs a study about stock density of baung fish baung fish juvenile. This study used Random Design analysis with different treatment of stocking density, they were 10 fishes/L (treatment A), 15 fishes/L (Treatment B), 20 fishes/L (Treatment $C$ ), and 25 fishes/L (Treatment $D$ ). The result showed that the different stocking density was affected the survival rate and the growth of Baung fish.
\end{abstract}

Keywords : Baung Fish, Stocking density, Survival rate, Growth.

\begin{abstract}
Abstrak
Ikan baung (Mystus numerus) adalah ikan asli Indonesia. Ikan ini banyak hidup di air tawar. Salah satu upaya pengembangan usaha perikanan dalam mengantisipasi penurunan hasil tangkapan dari perairan umum adalah melakukan pengembangan usaha budidaya perikanan secara berkesinambungan. Salah satu kendala dalam pembenihan ikan baung adalah rendahnya tingkat kelangsungan hidup dan pertumbuhan larva pada pemeliharaan dengan padat tebar yang tinggi dalam wadah terkontrol. Oleh karena itu dibutuhkan penelitian tentang padat tebar pemeliharaan benih ikan baung. Penelitian ini menggunakan Rancangan Acak Lengkap dengan perlakuan padat penebaran yang berbeda yaitu 10 ekor/Liter air (Perlakuan A) , 15 ekor/liter air (Perlakuan B), 20 ekor/liter air (Peerlakuan C) dan 25 ekor/liter air (Perlakuan D). Hasil penelitian menunjukkan bahwa padat penebaran yang berbeda memberikan pengaruh yang berbeda nyata terhadap kelangsungan hidup dan pertumbuhan benih ikan baung.
\end{abstract}

Kata kunci : Ikan Baung, padat penebaran. 


\section{PENDAHULUAN}

\section{Latar belakang}

Ikan baung (Mystus numerus)adalah ikan asli Indonesia. Ikan ini banyak hidup di air tawar. Daerah yang paling disukai adalah perairan yang tenang, bukan air yang deras. Karena itu, ikan baung banyak ditemukan di rawa-rawa, danau-danau, waduk dan perairan yang tenang lainnya. Meski begitu, ikan baung tetap memerlukan oksigen yang tinggi untuk kehidupannya. Seiring dengan tujuan pengembangan budidaya, pengembangan usaha budidaya ikan baung (M. numerus) merupakan salah satu sasaran khususnya di bidang pengembangan budidaya air tawar. Ikan baung $(M$. numerus) merupakan ikan konsumsi air tawar yang bernilai ekonomis tinggi. (Arie,2008)

Salah satu upaya pengembangan usaha perikanan dalam mengantisipasi penurunan hasil tangkapan dari perairan umum adalah melakukan pengembangan usaha budidaya perikanan secara berkesinambungan. Usaha ini sangat diharapkan dapat lebih berperan serta dalam menyediakan bahan makanan yang berprotein dan bernilai gizi yang tinggi, peningkatan peluang kerja dan mendorong kesejahteraan masyarakat serta pendapatan negara melalui kegiatan ekspor komoditi perikanan.

Dalam budidaya ikan baung (M. numerus) terdapat beberapa aspek kegiatan yang dilakukan, meliputi kegiatan pembenihan, pembesaran dan lain sebagainya. Beberapa jenis kegiatan pembenihan tersebut masih belum populer di kalangan masyarakat, karena umumnya masyarakat masih mengandalkan kegiatan penangkapan di alam dibandingkan dengan aspek budidaya ikan baung (M.numerus) yang masih minim dalam bidang produksi benih hingga ukuran konsumsi.

Khusus untuk kegiatan pembenihan, masih dilakukan di balai-balai benih milik pemerintah, misalnya kegiatan pembenihan secara intensif di Balai Budidaya Air Tawar (BBAT) Jambi dan balai-balai lainnya.

Kegiatan pembenihan merupakan upaya untuk menghasilkan benih pada ukuran tertentu.Namun demikian masih ditemukan beberapa kendala yang dihadapi pada tahapan kegiatan pembenihan, salah satu kendala tersebut adalah rendahnya tingkat kelangsungan hidup dan pertumbuhan larva pada pemeliharaan dengan padat tebar yang tinggi dalam wadah terkontrol.

Dari permasalahan di atas maka perlu dilakukan kajian pemeliharaan larva dengan padat penebaran yang berbeda pada tiap media.Dalam penelitian ini larva ikan baung dipelihara dalam wadah berupa akuarium dengan ukuran yang seragam dengan padat tebar yang berbeda. Dengan tujuan mengetahui kisaran optimal padat penebaran larva ikan baung selama penelitian.

\section{Tujuan dan Manfaat}

Penelitian ini bertujuan untuk melihat pengaruh padat penebaran larva ikan baung yang berbeda pada proses pemeliharaan larva terhadap pertumbuhan dan kelangsungan hidup larva ikan baung. Penelitian ini diharapkan bermanfaat bagi pembudidaya ikan, antara lain:

1. Meningkatkan hasil produksi perikanan terutama dari komoditas ikan baung melalui penggunaan teknologi budidaya yang tepat.

2. Mengetahui kisaran optimal padat penebaran larva ikan baung dalam wadah budidaya

3. Menambahkan pilihan konsumsi terhadap bahan pangan dari ikan.

4. Membuka lapangan usaha baru baik sebagai bisnis utama maupun usaha alternatif sehingga dapat meningkatkan pendapatan bagi pembudidaya ikan. 
Jurnal Akuakultur Sungai dan Danau Vol.1 No. 1 Tahun 2016 Hal 12 - 21

ISSN Online $2503-4766$

\section{Hipotesis}

Berdasarkan penelitian yang akan dilakukan, maka hipotesisnya adalah :

H0 : Tidak ada perbedaan terhadap kelangsungan hidup dan pertumbuhan larva ikan baung yang dipelihara dengan padat penebaran yang berbeda.

H1

: Ada perbedaan terhadap kelangsungan hidup dan pertumbuhan larva ikan baung yang dipelihara dengan padat penebaran yang berbeda.

\section{Waktu dan Tempat Penelitian}

\section{METODOLOGI PENELITIAN}

Penelitian Pengaruh Padat Penebaran Yang Berbeda TerhadapKelangsungan Hidupdan Pertumbuhan Larva Ikan Baung (Mystus numerus), dilaksanakan selama 16 hari dimulai dari tanggal 7 Pebuari2013 sampai 21Pebruari 2013. Tempat penelitian dilaksanakan di Balai Benih Ikan (BBI) Simpang Rimbo, Kota Jambi, Provinsi Jambi.

\section{Rancangan Penelitian}

Rancangan percobaan yang digunakan dalam penelitian ini adalah Rancangan Acak Lengkap ( RAL ) dengan 4 perlakuan dan 3 ulangan, dimana perlakuan tersebut adalah :

Perlakuan A : Pemeliharaan larva ikan baung dengan padat penebaran 10 ekor/ L (Kontrol)

Perlakuan B : Pemeliharaan larva ikan baung dengan padat penebaran 15 ekor/ L

Perlakuan C : Pemeliharaan larva ikan baung dengan padat penebaran 20 ekor/L

Perlakuan D : Pemeliharaan larva ikan baung dengan padat penebaran 25 ekor/L

Model rancangan percobaan yang digunakan adalah Rancangan Acak Lengkap (RAL) ( Steel dan Torrie,1989), adalah :

Keterangan :

$$
\mathrm{Yij}=\mu+\mathrm{Ti}+\mathrm{Eij}
$$

Yij = Nilai pengamatan unit percobaan yang mendapat perlakuan ke-I dengan ulangan ke-j.

$\mu \quad=$ Rata-rata umum

$\mathrm{Ti}=$ Pengaruh perlakuan ke-i

Eij = Pengaruh sisa dari unit percobaan yang mendapat perlakuan ke-i perlakuan ke-j

\section{Persiapan Percobaan}

Sebelum percobaan dilakukan dipersiapkan alat dan bahan yang akan digunakan dalam penelitian ini diantaranya adalah sebagai berikut :

\section{Persiapan Ikan Uji (Larva Ikan Baung)}

Larva ikan baung yang digunakan adalah hasil dari pemijahan secarabuatan. Induk yang digunakan adalah induk ikanbaung yang telah didomestikasi dan dipelihara secara intensif di Balai Budidaya Air Tawar Jambi. Tahapan kegiatan pemijahan yang dilakukan adalah seleksi induk, pemijahan secarabuatan, dan inkubasi telur.

\section{Wadah dan Alat Penelitian}

Wadah penelitian yang digunakan dalam penelitian ini adalah akuarium yang berukuran 100 x 50 x 40cm, sebanyak 12 buah dengan ketinggian air $10 \mathrm{~cm}$ dan volume air 50 liter. Masing-masing akuarium diberi label sesuai dengan pengacakan dan dilengkapi dengan aerasi.

Alat yang digunakan dalam penelitian ini adalah :timbangan digital, heater, $\mathrm{pH}$ meter, thermometer, serok, genset, seperangkat alat aerasi, Dissolved Oxygen meter. 
Jurnal Akuakultur Sungai dan Danau Vol.1 No. 1 Tahun 2016 Hal 12 - 21

ISSN Online $2503-4766$

\section{Pelaksanaan Percobaan}

Pada hari pertama hingga hari ketiga pemeliharaan, larva belum perlu diberi makan karena larva ikan baung masih memiliki cadangan makanan (yolk sack) dalam tubuhnya. Pemberian pakan dilakukan mulai hari keempat menggunakan kutu air (Daphnia) hingga larva berumur 10 hari. Pemberian pakan dilakukan secara satiasi dengan frekuensi pemberian5kali sehari, dimulai dari jam 07.00, 10.00, 13.00, 16.00 dan jam 19.00. Pemberianpakan juga dilakukan sedikit demi sedikit agar tidak terlalu banyak pakan yang tersisa.

Pada perlakuan A padat pemeliharaan larva ikan baung adalah 10 ekor/l, pada perlakuan B 15 ekor/l, perlakuan C 20 ekor/l dan untuk perlakuan D 25 ekor/l. Larva terlebih dahulu diaklimatisasikan, hal ini bertujuan larva yang ditebar tidak mengalami stress. Setelah itu larva ditebarkan ke akuarium penelitian yang sudah dilengkapi aerasi.

Selama pemeliharaan berlangsung dilakukan kegitan monitoring kondisi larva dengan mencatat jumlah larva yang mati setiap harinyadan mengamati kondisi kualitas air. Setiap haridilakukan penyiponan serta menambah kembali air media yang terbuang akibat penyiponan. Penyiponan dilakukan pada pagi hari agar kotoran di dasar akuarium dan kondisi kualitas air media pemeliharaan dapat terjaga dalam kondisi optimum.

Selama penelitian berlangsung, sampling dilakukan setiap satu minggu sekali dengan tujuan untuk mengetahui pertumbuhan yang terjadi pada larva ikan baung. Sampling dilakukan secara volumetrik dengan pengambilan sampel sebanyak $10 \%$ pada masing - masing perlakuan.

\section{Parameter yang Diamati}

\section{Tingkat Kelangsungan Hidup Ikan (Survival Rate)}

Penghitungan kelangsungan hidup larva dilakukan dengan cara menghitung jumlah larva yang hidup dan yang mati. Adapun rumus yang digunakan untuk menghitung Survival Rate (SR) menurut Effendi (1979) adalah:

$$
\mathrm{SR}=\frac{N t}{N o} x 100 \%
$$

Keterangan :

SR = Kelangsungan Hidup (SR)

$\mathrm{Nt} \quad=$ Jumlah ikan yang hidup pada akhir pemeliharaan (ekor)

No = Jumlah ikan yang hidup pada awal pemeliharaan (ekor)

\section{Pertambahan Panjang Larva Ikan Baung (Mystus numerus)}

Pengukuran pertambahan panjang total larva, dilakukan di awal dan di akhir penelitian dengan cara manual menggunakan mistar. Rumus yang digunakan menurut Wiryawan (2011) adalah :

Pertambahan panjang $=$ Panjang akhir - Panjang awal

\section{Pertambahan Berat Larva Ikan Baung ( Mystus numerus)}

Pengukuran pertambahan berat total larva, dilakukan di awal dan di akhir penelitian dengan cara manual menggunakan timbangan digital. Rumus yang digunakan menurut Wiryawan (2011) adalah :

Pertambahan Berat $=$ berat akhir - berat awal

\section{Kualitas Air}

Parameter kualitas air yang diamati dalam penelitian pengaruh padat penebaran ikan baung ini adalah : 
Jurnal Akuakultur Sungai dan Danau Vol.1 No. 1 Tahun 2016 Hal 12 - 21 ISSN Online $2503-4766$

Tabel 1. Parameter kualitas air dan spesifikasi metode pengamatan

\begin{tabular}{cccc}
\hline No & Parameter & Satuan & Spesifikasi Metode \\
\hline 1. & $\mathrm{Suhu}$ & ${ }^{\circ} \mathrm{C}$ & Thermometer \\
2. & $\mathrm{pH}$ & - & pH-Metri \\
3. & $\mathrm{DO}$ & $\mathrm{ppm}$ & DO-Metri \\
4. & $\mathrm{CO}_{2}$ & $\mathrm{ppm}$ & CO2-test kit \\
5. & $\mathrm{Ammonia}$ & $\mathrm{ppm}$ & SNI 06-2479-1991 \\
6 & $\mathrm{BOD}$ & $\mathrm{ppm}$ & SNI 06-2479-1991 \\
7 & $\mathrm{COD}$ & $\mathrm{ppm}$ & SNI 06-2479-1991 \\
8 & Nitrat dan Nitrit & $\mathrm{ppm}$ & SNI 06-2479-1991 \\
\hline
\end{tabular}

Uji kualitas air dilakukan di Badan Lingkungan Hidup Kabupaten Tanjung Jabung Timur dan air uji yang diamati adalahkondisi air diakhir penelitian

\section{Analisa Data}

Datayang diperoleh dari kegiatan penelitian ini di analisis menggunakan sidik ragam Anova(Analisis Of Variance)dan dilanjutkan dengan uji DNMRTtaraf 5\%. Data yang di analisa secara statistik meliputi SR (Survival Rate) dan pertambahan panjang larva dan berat larva, sedangkan data kualitas air akan dianalisa secara deskriptif.

\section{Kelangsungan hidup larva}

\section{HASIL DAN PEMBAHASAN}

Kelangsungan hidup larva ikan baung dari hasil pengamatan selama percobaan dapat dilihat pada lampiran 4. Dan rekapitulasi rata-rata hasil pengamatan tersebut dapat dilihat pada tabel di bawah ini.

Tabel 2. Persentase tingkat kelangsungan hidup larva ikan baung selama penelitian

\begin{tabular}{c|c}
\hline Perlakuan & SR (\%) \\
\hline A & $96,0^{\mathrm{a}}$ \\
B & $85,0^{\mathrm{b}}$ \\
C & $82,0^{\mathrm{c}}$ \\
D & $80,0^{\mathrm{c}}$ \\
\hline
\end{tabular}

Keterangan: Nilai yang dikuti huruf yang sama tidak berbeda nyata menurut uji jarak berganda Duncan pada tara 5\%

Berdasarkan tabel 2 di atas dapat diketahui bahwa semua perlakuan memiliki tingkat kelangsungan hidup yang berbeda tiap perlakuan, ini berarti padat penebaran berpengaruh terhadap kelangsungan hidup larva ikan baung. Tingginya tingkat kelangsungan hidup larva ikan baung sangat didukung oleh kualitas air dan padat penebaran yang optimum serta ketersediaan pakan yang sesuai bagi kehidupan larva.

Dari tabel 4 di atas dapat diketahui bahwa hasil pengamatan kelangsungan hidup tertinggi dicapai pada perlakuan A yaitu perlakuan dengan padat penebaran sebanyak 10 ekor/ liter. Persentase kelangsungan hidup pada perlakuan A(10 ekor/liter) yaitu sebesar sebanyak 96,0 \%, sedangkan tingkat kelangsungan hidup pada perlakuan B,C dan D secara berturut-turut adalah $85 \%, 82 \%$ dan $80 \%$, hal ini disebabkan karena padat penebaran yang berbeda menyebabkan penurunan kualitas air dan sedikitnya ruang gerak bagi larva ikan baung.

Menurut Hermawan, Iskandar, dan Subhan (2012), salah satu faktor yang 
mungkin dapat menyebabkan penurunan tingkat kelangsungan hidup pada kepadatan ikan yang meningkat adalah kualitas air yang menurun. Sementara menurut Effendi, Bugri, Widanami (2006), kematian yang terjadi pada saat pemeliharaan dengan kepadatan yang berbeda disebabkan oleh faktor ruang gerak yang semakin sempit sehingga memberikan tekanan terhadap ikan. Dampak dari stres mengakibatkan daya tahan tubuh ikan menurun bahkan terjadi kematian.

\section{Pertambahan Panjang Larva}

Berdasarkan pengamatan dan pengukuran terhadap penampilan larva selama penelitian, didapatkan data pertambahan panjang total larva ikan baung yang disajikan dalam Lampiran 8,sedangkan hasil pertambahan panjang larva ikan baung dapat dilihat dalam tabel di bawah ini.

Tabel 3. Pertambahan panjang total larva ikanbaung $(\mathrm{cm})$ selama penelitian

\begin{tabular}{c|c}
\hline Perlakuan & Pertambahan Panjang \\
\hline A & $2,30^{\mathrm{a}}$ \\
B & $1,55^{\mathrm{b}}$ \\
C & $1,41^{\mathrm{c}}$ \\
D & $1,50^{\mathrm{bc}}$ \\
\hline
\end{tabular}

Keterangan : Nilai yang dikuti huruf yang sama tidak berbeda nyata menurut ujijarak berganda Duncan pada tara 5\%

Berdasarkan tabel 3 di atas terlihat bahwa pertambahan panjang larva tertinggi dicapai pada perlakuan A yaitu pemeliharaan larva dengan padat penebaran 10 ekor/liter dengan pertambahan panjang pada akhir pemeliharaan sebesar $2,30 \mathrm{~cm}$, sementara pada perlakuan B, C, dan D berturut-turut adalah $1,55,1,41 \mathrm{~cm}$ dan $1,50 \mathrm{~cm}$. Namun dari hasil analisa statistik menunjukkan perbedaan yang tidak nyata antara perlakuan A, C, D dan berbeda nyata dengan perlakuan B. Hal ini disebabkan semakin tinggi kepadatan ikan makan akan semakin tinggi persaingan dalam perebutan makanan dan ruang gerakan bagi ikan.

Ruang gerak juga merupakan faktor luar yang mempengaruhi laju pertumbuhan, dengan adanya ruang gerak yang cukup luas ikan dapat bergerak dan memanfaatkan unsur hara secara maksimal (Rahmat, 2010). Pada padat penebaran yang tinggi ikan mempunyai daya saing di dalam memanfaatkan makanan, unsur hara dan ruang gerak, sehingga akan mempengaruhi laju pertumbuhan ikan tersebut.

Pertumbuhan adalah total energi yang diubah menjadi penyusun tubuh, kebutuhan energi ini diperoleh dari makanan. Pertumbuhan juga merupakan suatu proses pertambahan bobot maupun panjang tubuh ikan, adapun perbedaan laju pertumbuhan dapat disebabkan karena adanya pengaruh padat penebaran dan persaingan di dalam mendapatkan makanan.(Hernowo, 2001). Padat tebar yang tinggi akan mengganggu laju pertumbuhan meskipun kebutuhan makanan tercukupi. Hal ini disebabkan karena adanya persaingan dalam memperebutkan makanan dan ruang. (Kordik, 2005).

\section{Pertambahan Berat Larva}

Berdasarkan pengamatan dan pengukuran terhadap berat larva selama penelitian, didapatkan data pertambahan berat total larva ikan baung yang disajikan dalam Lampiran 12, sedangkan hasil pertumbuhan berat larva ikan baung dapat dilihat dalam 
Jurnal Akuakultur Sungai dan Danau Vol.1 No. 1 Tahun 2016 Hal 12 - 21

ISSN Online $2503-4766$

tabel di bawah ini.

Tabel 4. Pertambahan Berat total larva ikanbaung (gram) selama penelitian

\begin{tabular}{c|c}
\hline Perlakuan & Pertambahan Berat (gram) \\
\hline A & $2.48^{\mathrm{a}}$ \\
$\mathrm{B}$ & $2,02^{\mathrm{ab}}$ \\
$\mathrm{C}$ & $1,38^{\mathrm{b}}$ \\
$\mathrm{D}$ & $1,78^{\mathrm{ab}}$ \\
\hline
\end{tabular}

Keterangan : Nilai yang dikuti huruf yang sama tidak berbeda nyata menurut uji jarak berganda Duncan pada tara 5\%

Berdasarkan tabel 4 di atas terlihat bahwa pertambahan beratlarva tertinggi dicapai pada perlakuan A yaitu pemeliharaan larva dengan padat penebaran 10 ekor/liter dengan pertambahan berat pada akhir pemeliharaan sebesar 2,48gram, sementara pada perlakuan B, C, dan D berturut-turut adalah 2,02, 1,38 gram dan 1,78gram. Namun dari hasil analisa statistik menunjukkan perbedaan yang tidak nyata antara perlakuan A, B, $\mathrm{D}$ dan berbeda nyata dengan perlakuan $\mathrm{C}$.

Menurut Fatimah (2002), semakin tinggi padat penebaran ikan maka akan menghasilkan produksi yang tinggi. Tetapi ikan yang dihasilkan tidak seragam jika dibandingkan dengan padat tebar yang rendah. Hal ini terjadi karena tinggi padat penebaran, maka semakin tinggi pula kompetisi dalam memperoleh makanan dan ruang gerak.

Menurut Asmawidalam Permana (2013), menyatakan bahwa semakin besar kepadatan ikan yang kita berikan, akan semakin kecil laju pertumbuhan perindividu. Dengan kepadatan rendah ikan mempunyai kemampuan memanfaatkan makanan dengan baik dibandingkan dengan kepadatan yang cukup tinggi, karena makanan merupakan faktor luar yang mempunyai peranan di dalam pertumbuhan. Kekurangan pakan akan memperlambat laju pertumbuhan sehingga dapat menyebabkan kanibalisme, sedangkan kelebihan pakan akan mencemari perairan sehingga menyebabkan ikan stres dan menjadi lemah serta nafsu makan ikan akan menurun.

\section{Kualitas air}

Dari pengamatan kualitas air yang dilakukan selama penelitian didapatkan data berupa Suhu, pH, BOD, COD, DO (Dissolved Oksigen), Amoniak, Nitrat, Nitrit yang disajikan dalam tabel pengamatan harian dan rekapitulasi pada tabel 6 dibawah ini.

Tabel 5. Kualitas Air Pada Akhir Media Pemeliharaan

\begin{tabular}{|c|c|c|c|c|c|c|c|c|}
\hline \multirow[b]{2}{*}{ PERLAKUAN } & \multicolumn{8}{|c|}{ PARAMETER } \\
\hline & $\begin{array}{c}\text { Suhu } \\
\left({ }^{\circ} \mathrm{C}\right)\end{array}$ & pH & $\begin{array}{c}\text { BOD } \\
\text { (ppm) }\end{array}$ & $\begin{array}{c}\text { COD } \\
\text { (ppm) }\end{array}$ & $\begin{array}{c}\text { DO } \\
\text { (ppm) }\end{array}$ & $\begin{array}{c}\text { Amon } \\
\text { iak } \\
(\mathbf{p p m})\end{array}$ & $\begin{array}{l}\text { Nitrat } \\
(\mathbf{p p m})\end{array}$ & $\begin{array}{l}\text { Nitrit } \\
(\mathbf{p p m})\end{array}$ \\
\hline A & 30 & 7,9 & 3,34 & 7,4 & 8,75 & 0,19 & 0,1 & 0,006 \\
\hline B & 30 & 7,9 & 3,3 & 7,2 & 8,23 & 0,30 & 0,2 & 0,017 \\
\hline $\mathrm{C}$ & 29 & 7,8 & 2,5 & 6,6 & 8,32 & 0,31 & 2,6 & 0,016 \\
\hline $\mathrm{D}$ & 28 & 7,8 & 3,2 & 7,1 & 7,25 & 0,37 & 1,3 & 0,020 \\
\hline
\end{tabular}


Berdasarkan tabel tersebut dapat diketahui bahwa suhu air untuk semua perlakuan berkisar antara $28^{\circ} \mathrm{C}-30^{\circ} \mathrm{C}$, kisaran suhu tersebut masih dalam batas toleransi larva ikan baung. Didalam pelaksanaan penelitian ini digunakan pemanas (heater) untuk menghindari terjadinya fluktuasi suhu terutama pada malam hari. Taufik (2006) menjelaskan bahwa suhu air yang optimal akan memacu aktivitas enzim dalam lambung sehingga laju pengosongan lambung meningkat dan merangsang hypothalamus (sensor kenyang dan lapar) sehingga larva jadi cepat lapar, akibatnya aktivitas makan meningkat dan menghasilkan pertumbuhan yang lebih cepat.

Faktor lain yang juga dapat mendukung meningkatnya laju pertumbuhan adalah media pemeliharaan yang optimal, menurut Zonneveld et al (1991), faktor lingkungan juga berpengaruh dalam pemanfaatan energi, pada kondisi lingkungan yang buruk ikan memanfaatkan energi yang diperoleh dari makanan untuk mempertahankan hidup dari pada untuk pertumbuhan.

Untuk DO (Dissolved Oxygen) atau oksigen terlarutselama masa penelitian tersedia dengan baik yaitu berkisar antara 7,25 - 8,25 mg/l. Rizal dalam Yonanda (2011) menjelaskan, apabila ketersediaan oksigen terlarut kurang memadai dan konsentrasinya rendah maka akan menyebabkan pertumbuhan yang lambat, nafsu makan ikan berkurang serta menyebabkan kematian.

$\mathrm{pH}$ air juga sangat berperan penting dalam suatu kegiatan budidaya, dalam percobaan ini didapatkan $\mathrm{pH}$ air berkisar antara $7.8-7,9$. Hal ini menunjukkan $\mathrm{pH}$ air termasuk dalam keadaan normal. Effendi(2000) mengatakan nilai pH air pada kondisi asam tidak baik untuk budidaya ikan, dimana produksi ikan dalam suatu perairan akan rendah, sedangkan pada $\mathrm{pH}$ air basa juga tidak baik untuk kegiatan budidaya. Pengaruh $\mathrm{pH}$ air pada perairan dapat berakibat terhadap komunitas biologi perairan.

Kandungan ammoniak air sangat berperan penting dalam suatu kegiatan budidaya.Kadar ammonia pada periran alami biasanya kurang dari 0,1 mg/l (Neely dalam Effaedi, 2000). Kadar ammoniak bebas yang tidak terionisai $\left(\mathrm{NH}_{3}\right)$ pada periran tawarsebaiknya tidak melebihi $0,02 \mathrm{mg} / \mathrm{l}$. Kadar ammonia bebas melebihi $0,2 \mathrm{mg} / \mathrm{l}$ bersifat toksik bagi beberapa jenis ikan (Sawyer dan Carty dalam Effendi, 2000). Dalampenelitian ini didapatkan kandungan amoniak air berkisar antara 0,19-0,37 $\mathrm{mg} / \mathrm{l}$.Kadar ammoniak yang tinggi dapat merupakan indikasi adanya pencemaran bahan organik yang berasal dari limbah domestic, industri, dan limpasan (Run - Off) pupuk pada pertanian. Kadar amoniak yang tinggi juga bisa ditemukan pada dasar danau yang mengalami kondisi tanpa oksigen (anoxic).Kandungan ammoniak yang didapat pada saat penelitian relatip tinggi.Namun tidak terlalu berpengaruh terhadap kelangsungan hidup larva ikan baung, karena ikan baung merupakan ikan catfish, yang mampu bertahan hidup dengan kosentrasi amoniak yang tinggi.

Nitrit biasanya ditemukan dalam jumlah yang sangat sedikit diperairan alami, kadarnya lebih kecil dari nitrat karena nitrit bersifat tidak stabil jika terdapat oxygen. Nitrit merupakan bentuk peralihan antara amonia dan nitrat. Selama penelitian didapatkan kadar nitrit sebesar 0,006 ppm, kondisi ini masih dalam keadaan baik. Menurut Effendi (2000), kadar diperairan sekitar 0,001 dan sebaiknya tak melebihi $0,006 \mathrm{ppm}$. Diperairan kadar nitrit jarang melebihi $1 \mathrm{ppm}$. Kondisi nitri yang tinggi dapat mengakibatkan terganggunya proses pengikatan oksigen oleh hemoglobin darah yang selanjutnya membentuk methemoglobin yang tak mampu mengikat oksigen.

Sementara untuk nitrat adalah bentuk nitrogen utama diperairan alami, selama penelitian berlangsug kadar nitrat didapatkan 0,1 ppm. Menurut Effendi (2000), kadar nitrat yang melebihi $5 \mathrm{ppm}$ menggambarkan terjadinya pencemaran antropogenik yang 
berasal dari feses ikan.

Untuk nilai BOD diperiran dipengaruhi oleh suhu, densitas plangkton dan keberadaan mikroba, serta jenis dan kandungan bahan organik. Sumber bahan organik pada perairan alami dalah pembusukan tanaman. Selama penelitian nilai BOD mencapai 3,34 ppm, Menurut Jeffries dan Mills dalam Effendi (2000),Perairan alami memiliki BOD berkisar antara 0,5 - 7,0 mg/l. Periran dengan nilai BOD melebihi $10 \mathrm{mg} / \mathrm{l}$ dianggap telah mengalami pencemaran.

COD menggambarkan jumlah total oksigen yang dibutuhkan untuk mengoksidasi secara kimiawi bahan organik, baik yang bisa didegradasi secara biologis (biodegradable) maupun yang sukar didegradasi secara biologis (nonbiodegradable), menjadi $\mathrm{CO}_{2}$ dan $\mathrm{H}_{2} \mathrm{O}$. Pada proses penentuan $\mathrm{COD}$, oksigen yang dikonsumsi setara dengan jumlah dikromatyang diperlukan dalam mengoksidasi air sampel. (Boyd dalam Effendi 2000).

Jika pada perairan terdapat bahan organik seperti selulosa, tannin, lignin, fenol, polisakarida, benzena dan lain - lain yang resisten terhdap degradasi biologis maka pengukuran COD akan lebih sesuai dibandigkan dengan penentuan Nilai BOD.

\section{KESIMPULAN}

Berdasarkan hasil penelitian yang didapatkan, dapat disimpulkan bahwa:

1. Bahwa hasil pengamatan kelangsungan hidup tertinggi dicapai pada perlakuan $\mathrm{A}$ yaitu perlakuan dengan padat penebaran sebanyak 10 ekor/ liter. Persentase kelangsungan hidup pada perlakuan A (10 ekor/liter) yaitu sebesar sebanyak $96 \%$, sedangkan tingkat kelangsungan hidup terendah terletak pada perlakuan D sebesar80\%,

2. Pertambahan panjang larva tertinggi dicapai pada pemeliharaan larva dengan padat penebaran 10 ekor/liter dengan panjang total pada akhir pemeliharaan sebesar $2,33 \mathrm{~cm}$, sementara pada perlakuan B, C, dan D berturut-turut adalah $2,25,2,11 \mathrm{~cm}$ dan $2,20 \mathrm{~cm}$. Namun dari hasil analisa statistik menunjukkan perbedaan yang tidak nyata antara perlakuan A, C, D dan berbeda nyata dengan perlakuan B.

3. Pertambahan beratlarva tertinggi dicapai pada pemeliharaan larva dengan padat penebaran 10 ekor/liter dengan bobot total pada akhir pemeliharaan sebesar $2,63 \mathrm{~cm}$, sementara pada perlakuan B, C, dan D berturut-turut adalah $2,17,1,53 \mathrm{~cm}$ dan $1,93 \mathrm{~cm}$. Namun dari hasil analisa statistik menunjukkan perbedaan yang tidak nyata antara perlakuan A, B, D dan berbeda nyata dengan perlakuan C.

4. Secara keseluruhan penelitian ini berjalan dengan baik, karena hasil yang didapat rata - rata diatas $80 \%$

\section{DAFTAR PUSTAKA}

Anoraga. 2012. Lingkungan ideal bagi ikan lele.

http://www.mycatfish.com/2012/06/lingkungan-ideal-bagi-ikan-

lele.html\#ixzz205QPCxIu

Arie.U. 2008 Seputar Budiddaya Ikan. Jakarta : Penebar Swadaya.

Bagus. 2011. Mengenal jenis ikan baung. Fakultas Perikanan Univeristas Airlangga.

Surabaya. http://bagusrn-fpk09.web.unair.ac.id/artikel_detail-35817-PerikananMengenal\%20Jenis\%20Ikan\%20Baung.html

Bughri. H.J, Effendi. I, Widanarni. 2006. Pengaruh Padat Penebaran Terhadap Kelangsungan Hidup Benih Ikan Gurami 2 Inc.

Effendi, M, I., 1979. Biologi Perikanan. Penerbit Yayasan Pustaka Nusatama, 
Jurnal Akuakultur Sungai dan Danau Vol.1 No. 1 Tahun 2016 Hal 12 - 21

ISSN Online 2503 - 4766

Yogyakarta

Effendi. H. 2000. Telaahan Kualitas Air. Jurusan Manajemen Sumber Daya Peraiaran.

Fakultas Perikanan Dan Ilmu Kelautan. IPB.

Effendi. I, Bugri. H.J, Widanarni. 2006. Pengaruh padat penebaran terhadap kelangsungan hidup dan pertumbuhan ikan gurami ukuran $2 \mathrm{~cm}$. Departemen

Budidaya Perairan Fakultas Perikanan dan Ilmu Kelautan. IPB

Fatimah. S. 2002. Pengaruh Padat Penebaran Terhadap Pertumbuhan dan konversi pakan ikan Lele Dumbo (Clarias gariepenus) dalam kerambah jarring apung diwaduk jati luhur. Skripsi. Fakultas Pertanian jurusan perikanan. Universitas Padjajaran

Ferraris, Carl J., Jr. (2007). "Checklist of catfishes, recent and fossil (Osteichthyes: Siluriformes), and catalogue of siluriform primary types" (PDF). Zootaxa1418: 1628.

Hermawan. T. A, Iskandar, Subhan. U. 2012. Pengaruh Padat Tebar Terhadap Kelangsungan Hidup dan Pertumbuhan Ikan Lele Dumbo (Clarias Gariepenus)

Herman. 2011. Teknik Pembenihan Ikan Patin Siam. http://kreasi

hermanoceaniz.blogspot.com/2011/04/teknik-pembenihan-ikan-patinsiam.html

Hernowo. 2001. Pembenihan Patin Skala Kecil dan Besar, Solusi Permasalahan. Penerbar Swadaya, Jakarta.

Kordik. M.G.H.2005. Budidaya Ikan Patin, Biologi, Pembenihan dan Pembesaran. Yayasan Pustaka Nusantara. Yogyakarta.

Lukito AM. 2002. Lele Ikan Berkumis Paling Populer. Agromedia. Jakarta

Permana. E. 2013. Laju Pertumbuhan Ikan Patin

Rahmat. 2010. kepadatan ikan khususpatin.

Steel and Torrie. (1989). Reproduced from Principles and Procedures of Statistics.Mc Graw Hill Book Co. Inc, New York.

Syafrudin. D, Yuniarti, Setiawati. M. 2006. Pengaruh Kepadatan Benih Ikan Lele Dumbo (Clarias sp.) Terhadap Produksi Pada Sistem Budidaya Dengan Pengendalian Nitrogen Melalui Penambahan Tepung Terigu.

Tang.M.U. 2008 Mengenal ikan Baung ( M. numerus).Perikanan Indonesia.

Taufik, I, dkk. (2006). Pemeliharaan larva ikan betutu dengan periode penyinaran yang berbeda. Jurnal riset akuakultur vol. 1 no. 3 hal 431-436. Pusat riset perikanan budidaya. Pasar Minggu

Utiah.A. 2006. Penampilan reproduksi induk ikan baung ( $M$. numerus ) dengan pemberian pakan buatan yang ditambahkan asam lemak n-6 dan n-3 dan imlantasi estradiol $17 \beta$ dan tiroksin , Pasca sarjana Institut Pertanian Bogor

Wiryawan, Rangga (2011). Pemberian kuning telur ayam sebagai pakan alternatif pada fase kritis larva ikan betok (Anabas testudineus) pada fase kritis.

Yonanda. A. 2012. Pengaruh Pemberian Sari Nabati Terhadap Kelangsungan Hidup Larva Ikan Tambakan (Helosstoma temenckii). Skripsi. Jurusan Budiddaya Perairan Fakultas Pertanian Unbari Jambi.

Zonneveld, N. (1991). Prinsip-prinsip budidaya ikan. Gramedia PustakaUmum. Jakarta 